\title{
Viele Helden für viele Leser \\ Das Heroische in viktorianischen Publikumszeitschriften
}

\author{
Barbara Korte
}

\section{Einleitung: Helden und Zeitschriften in der viktorianischen Gesellschaft}

Dieser Beitrag betrachtet die Darstellung und Verhandlung des Heroischen in einem Massen- und Leitmedium des 19. Jahrhunderts: Publikumszeitschriften (das heißt Veröffentlichungen für eine allgemeine Leserschaft im Gegensatz zu Fachzeitschriften) wollten die breite Öffentlichkeit erreichen, suchten die Nähe zur Lebenswirklichkeit und -praxis ihrer Leserschaften und waren sich bewusst, eine gemeinschaftsstiftende Funktion zu erfüllen. Sie durchdrangen den Alltag ihrer Leser und moderierten gesellschaftliche Diskurse, meist in einer Mischung verschiedener faktualer und fiktionaler Genres wie Essays, Biographien, Kurzgeschichten, Fortsetzungsromane und Gedichte. Publikumszeitschriften eignen sich deshalb in besonderer Weise für eine Untersuchung, wie das Thema und die Diskurse des Heroischen für Lesermassen aufbereitet wurden - und zwar zu einer Zeit, in der die Masse als soziale und politische Einheit hoch präsent und brisant war.

Meine Ausführungen konzentrieren sich auf das viktorianische Großbritannien ab 1850, das in zweifacher Hinsicht einen besonders fruchtbaren Boden für die folgenden Betrachtungen bietet:

1. Zwar expandierte der Zeitschriftenmarkt um die Mitte des 19. Jahrhunderts überall in Europa, aber Großbritannien stand an der Spitze dieser Entwicklungen. „Nineteenth-Century Britain“, so schreiben Jerry D. Vann und Rosemary VanArsdel, „was uniquely the age of the periodical“, 1 und Richard Altick konstatiert in seiner wegweisenden Studie über den „English Common Reader“:

„Great as was the increase in book production between 1800 and 1900, the expansion of the periodical industry was greater still. This was only natural, for of all forms of reading matter, periodicals - including newspapers - are best adapted for the needs of a mass audience. They can be produced and sold much more cheaply than books. They appeal to the millions of men and women who consider the reading of a whole book too formidable a task even to be attempted." 2

1 J. D. Vann / R. T. VanArsdel (Hrsg.), Victorian Periodicals and Victorian Society, Toronto 1994, S. 7.

2 R. D. Altick, The English Common Reader: A Social History of the Mass Reading Public, 1800-1900, Columbus, OH 21998 [zuerst 1957], S. 318. Zur allgemeinen Bedeutung des Printkapitalismus für die Bildung von Gemeinschaften siehe auch B. Anderson, Imagined 
2. Das Heroische wurde in der viktorianischen Gesellschaft nicht nur propagiert, sondern auch kritisch inspiziert, da durchaus unterschiedliche Vorstellungen über Heldentum, seine Signifikanz und Funktionen zirkulierten.

$\mathrm{Zu}$ diesen Vorstellungen gehörte Thomas Carlyles bedauernde und weit gehörte Feststellung, dass in einer verbürgerlichten und modernen Gesellschaft die Zeit der Heldenverehrung vorüber sei: „I am well aware that in these days Heroworship, the thing I call Hero-worship, professes to have gone out, and finally ceased. This [...] is an age that as it were denies the existence of great men; denies

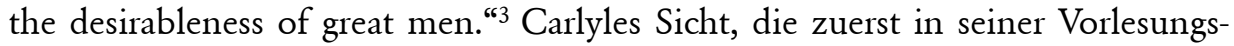
reihe des Jahres 1840 formuliert wurde, ist postromantisch, elegisch und elitär. Sie lokalisiert Helden in Göttern und göttlich inspirierten Propheten, Poeten, Herrschern und anderen ,großen Männern', die modellieren, was die breite Masse („the general mass of men“4) tun und erreichen kann. Diese Führergestalten können zwar der Masse entstammen, aber sie erheben sich aus ihr, weil sie einen Funken der Inspiration in sich tragen. ${ }^{5}$

Dies sah ein anderer Denker der Epoche anders: In „Self-Help“ (1859) propagierte Samuel Smiles, ebenfalls höchst einflussreich, dass gesellschaftlicher Erfolg jedem offen stünde, der zu Anstrengung, zum Durchhalten, zum Ertragen von Rückschlägen und Leid bereit sei, ${ }^{6}$ und für Smiles waren Menschen, die diese Eigenschaften beispielhaft verkörperten, Helden - egal ob sie tradierten heroischen Repertoires entstammten oder neueren Gesellschaftstypen wie den Erfindern, Wissenschaftlern und Unternehmern, die den viktorianischen Fortschritt mitbestimmten. ${ }^{7}$ Wo Carlyle über Helden schrieb, von denen sich die Masse fübren lassen sollte, stellte Smiles seinen Lesern Helden vor, denen sie nachstreben konnten. Carlyle und Smiles waren bereits in ihrer eigenen Zeit prominente Referenzautoren für Diskussionen über das Heroische, wobei Smiles die größere Anschlussfähigkeit für eine sich demokratisierende Gesellschaft hatte.

Communities: Reflections on the Origin and Spread of Nationalism, London 1983, besonders S. 30-31 sowie S. 41-49.

3 T. Carlyle, On Heroes, Hero-Worship and the Heroic in History, London 1841 (Nachdr. London 1901), S. 12.

4 Ebd., S. 1.

5 Die Rezeption Carlyles bis in das späte 19. Jahrhundert lässt sich an den Neuauflagen von „On Heroes“ ablesen. 1880 wurde eine solche Neuauflage zum Beispiel in einer Annonce in der populären Zeitschrift „All the Year Round“ beworben, ebenso wie andere Publikationen zu Helden.

6 Siehe zu Smiles auch A. Jarvis, Samuel Smiles and the Construction of Victorian Values, Stroud 1997.

7 Gerade über diese Erfolgstypen der viktorianischen Gesellschaft verfasste Smiles auch zahlreiche Biographien, wie „Lives of the Engineers“ (1862) und „Men of Invention and Industry" (1884). Zur Heroisierung von Erfindern siehe auch C. MacLeod, Heroes of Invention: Technology, Liberalism and British Identity, 1750-1914, Cambridge 2007, S. 1: „The inventor was an improbable hero. [...] [H]e toiled in an anonymous workshop, far from the glorious field of battle, or the terrors of the ice floes, the desert, or the jungle". 
Dass diese Demokratisierung zu Erweiterungen und Verschiebungen in der Definition des Heroischen führte, lässt sich an Publikumszeitschriften deutlich ablesen. Denn obwohl die viktorianischen Publikumszeitschriften als Massenmedium bezeichnet werden können, das alle lesekundigen Teile der Öffentlichkeit erreichte, richtete sich das Angebot einer einzelnen Zeitschrift konkret immer an ein Teilpublikum dieser Öffentlichkeit. Das Angebot der Zeitschriften war also gefächert, und so ist in ihnen nicht nur viel von Helden die Rede, sondern auch vielfältig. Zwar zeigt sich in meinen späteren Beispielen ein grundlegender ideologischer Konsens in Hinblick auf positive Heldenmodelle, die Bedeutung und den Wert des Heroischen, aber immer zugeschnitten auf ein bestimmtes Teilpublikum.

\section{Publikumszuschnitte und-strategien der Zeitschriften}

Abgesehen von der Variation zwischen Zeitschriften ist für die Aufbereitung des Heroischen in viktorianischen Publikumszeitschriften entscheidend, dass es sich hierbei meist um den Typus des Magazins und damit ein heterogenes Medium handelt: ${ }^{8}$ Jede einzelne Ausgabe einer solchen Zeitschrift setzt sich aus Beiträgen von verschiedenen Verfassern zu verschiedenen Themen und in der Regel in verschiedenen Textgattungen zusammen. Die Zeitschriften konfrontieren ihr jeweiliges Publikum also nie nur mit einem Heldenmodell oder -diskurs, sondern immer mit einem Geflecht heroischer Figurationen. Und sie tun dies mit einem besonders engen Publikumsbezug, der der Konkurrenz um Leser auf dem florierenden Zeitschriftenmarkt des späten 19. Jahrhunderts geschuldet ist. Für kommerziell verbreitete Zeitschriften waren Leser Kunden, um die gekämpft werden musste, und zwar mit sehr ähnlichen Mitteln wie auf dem heutigen Medienmarkt. ${ }^{9}$ Selbst für nichtkommerzielle (etwa von religiösen Trägern verbreitete) Publikationen stellte sich angesichts der großen Fülle erhältlicher Zeitschriften das Problem einer „Ökonomie der Aufmerksamkeit". 10

Zeitschriften griffen für das Gewinnen dieser Aufmerksamkeit auf verschiedene Strategien zurück. Die fundamentalste war der schon angesprochene Zuschnitt auf kleinere oder größere Teilpublika. Die Zeitschriften waren bestrebt, die Anschauungen und Interessen ihrer intendierten Leserschaften zu bedienen, das heißt, sie ließen sich einerseits von Leserinteressen leiten, wollten andererseits aber auch Interessen kanalisieren und die Ideale und Werte ihrer Herausgeber, Verleger und gegebenenfalls institutionellen Träger vermitteln. Für solche Zwecke konstruierten Zeitschriften ihre angenommene Leserschaft als Gemeinschaft, zu der sie - bzw.

8 Vgl. M. Beetham, A Magazine of Her Own? Domesticity and Desire in the Woman's Magazine, 1800-1914, London 1996, S. 1.

9 Vgl. zur Kundenbindung heute etwa D. Rogall, Kundenbindung als strategisches Ziel des Medienmarketing, Marburg 2000.

10 Vgl. den für den Wissenschaftsbetrieb geprägten Begriff von G. Franck, Ökonomie der Aufmerksamkeit. Ein Entwurf, München 1998. 
ihre Herausgeber - ein freundschaftliches, geradezu vertrautes Verhältnis pflegen wollten.

Das Vorwort von Charles Dickens für die erste Ausgabe seiner populären Zeitschrift „Household Words“ betont diese Absicht ausdrücklich, und zwar für Leser "of both sexes, and of all ages and conditions": „We aspire to live in the Household affections, and to be numbered among the Household thoughts, of our readers". ${ }^{11}$ Dickens erwartet von seiner Zeitschrift geradezu einen gemeinschaftsbildenden Effekt: „to bring the greater and the lesser in degree, together, [...] and mutually dispose them to a better acquaintance and a kinder understanding“. ${ }^{12}$ Eine andere große Publikumszeitschrift, die „Leisure Hour“, bekundete in ihrem ersten programmatischen Vorwort ebenfalls die Absicht, ein Freund des Lesers werden zu wollen: „we are actuated by a desire, the very condition of future usefulness, to make as many friends as possible“. Auch hier wird betont, dass die Zeitschrift zum Leser nach Hause, in seine private Lebenswelt, kommen und ihn dort erbauen will mit „every virtue which ought to elevate and gladden our English home“. Wiederum wird das Bild einer intimen Nähe zwischen dem intendierten Publikum und einer Zeitschrift entworfen, die sich geehrt gibt, vom Leser in sein Wohnzimmer eingeladen zu werden: „[to] have the honour of being introduced to the amenities of his fireside; of talking to him with the easy confidence of a friend“. Dabei imaginierte die „Leisure Hour" eine in sich diverse Leserschaft, die gleichwohl eine nationale Einheit bildete:

„We dedicate our pen to the thoughtful of every class. We aspire to catch the attention of peer and peasant, of master and man. From the highest to the lowest, there is no circle from which we desire to exclude ourselves; and none, we would fain hope, which will be disposed to exclude us. Our sympathies are universal; and though they will adapt themselves to the special circumstances of different classes, they will vibrate, we trust, with the love towards all. And why should they not? Are we not one people, one great commonwealth?"13

11 C. Dickens, Preliminary Word, in: Household Words, 1. März 1850, S. 1. Alle Zeitschriftenartikel werden im Folgenden mit dem Datum des jeweiligen Zeitschriftenheftes und Seitenzahlen zitiert. In der Regel erschienen die Artikel ohne Autorenangaben. „Household Words“ (HW) und „All the Year Round“ (AYR) werden zitiert nach den Faksimiles in der frei zugänglichen Datenbank Dickens Journals Online, The University of Buckingham, www.djo.org.uk; die anderen Zeitschriften nach den Digitalisaten in der Datenbank Nineteenth Century UK Periodicals (für „Boy’s Own Magazine“ [BOM] und „Englishwoman’s Domestic Magazine“ [EDM]) sowie der Datenbank ProQuest (für „Leisure Hour“ [LH]).

12 Als Dickens nach neun Jahren aufgrund von Konflikten mit seinem Verleger „Household Words" beendete, aber mit „All the Year Round“ quasi fortsetzte, strebte er sogar noch eine Erweiterung seiner Leserschaft an, wie einer Ankündigung der neuen Zeitschrift in „Household Words“ zu entnehmen ist: „I look, and plan, for a very much wider circle of readers, and yet again for a steadily expanding circle of readers“, HW, 28. Mai 1850, S. 479.

13 H. D., Word with Our Readers, in: LH, 1. Januar 1852, S. 8-10, hier S. 8-9. Die Konstruktion einer Lesergemeinschaft bedeutete allerdings nicht unbedingt, dass einzelne Leser sich immer mit diesem Konstrukt identifizierten. Beth Rodgers konnte am Beispiel zweier 
Viktorianische Publikumszeitschriften konstruierten für ihre Leserschaft(en) also einen Gestus der Nähe und sie redeten, wie sich später zeigen wird, die Leser in einzelnen Beiträgen auch explizit an.

Viele dieser Beiträge waren Teil von Serien, einem noch immer genutzten Prinzip der Rezipienten- bzw. Kundenbindung. ${ }^{14}$ Zudem betrieben die Zeitschriften Werbung und Selbstwerbung und nutzten Strategien, die man heute mit Begriffen wie ,partizipativer Journalismus fasst: ${ }^{15}$ Leser und Leserinnen wurden zur Korrespondenz mit dem Herausgeber ${ }^{16}$ und zur aktiven Mitwirkung an der Publikation aufgefordert, besonders in Form von Wettbewerben, bei denen man Essays oder Gedichte einreichen konnte und wo es hochwertige Preise zu gewinnen gab, mit denen dann wiederum geworben werden konnte. So annoncierte das erste Heft der Knabenzeitschrift „Boy’s Own Magazine“ gleich unter dem Titelblock: „Suitable Prizes, of not less value than One Hundred Guineas, annually distributed amongst the Purchasers", und das Herausgeberwort des Heftes endet mit dem Hinweis:

„The first annual gift with the Boys' [sic] Own Magazine will be TWENTY SILVER WATCHES, of the full value of five guineas each. [...] The Publishers have also the intention, if the Magazine is well supported, of increasing the gifts by the addition of a number of Gold and Silver Penholders and Pencil Cases. ${ }^{\text {"17 }}$

Als immaterielle Anerkennung wurden die Einsendungen gelistet und kommentiert, Gewinner-Essays wurden abgedruckt: entweder im „Boy’s Own Magazine“ selbst oder in einer separaten Buchausgabe. Die Leserinnen des „Englishwoman's Domestic Magazine“ erhielten für ihre Essays Schreibtipps durch den Herausgeber, der ihnen das Begräbnis eines nationalen Helden, des Duke of Wellington, als geeignetes Übungsthema vorschlug. ${ }^{18}$

Mädchenzeitschriften der spätviktorianischen Epoche nachweisen, dass sich individuelle Leserinnen der Vergemeinschaftung entzogen: B. Rodgers, Competing Girlhoods: Competition, Community, and Reader Contribution in "The Girl's Own Paper" and "The Girl's Realm”, in: Victorian Periodicals Review 45, Heft 3, 2012, S. 277-300. Die Möglichkeit solch individueller Rezeptionsstudien ist stark abhängig davon, inwieweit Archive von Verlagen erhalten und darin auch Leserzuschriften bewahrt wurden. Sie ist daher nur in Einzelfällen möglich.

14 Vgl. zur Serialität neuere Publikationen wie F. Kelleter (Hrsg.), Populäre Serialität: Narration - Evolution - Distinktion. Zum seriellen Erzählen seit dem 19. Jahrhundert, Bielefeld 2012; G. Eschke / R. Bohne, Bleiben Sie dran! Dramaturgie von TV-Serien, Konstanz 2010; C. Mielke, Zyklisch-serielle Narration: Erzähltes Erzählen von 1001 Nacht bis zur TV-Serie, Berlin 2006.

15 Vgl. etwa S. Engesser, Partizipativer Journalismus: Eine Begriffsanalyse, in: A. Zerfaß [et al.] (Hrsg.), Kommunikation, Partizipation und Wirkungen im Social Web: Strategien und Anwendungen. Perspektiven für Wirtschaft, Politik und Publizistik, Köln 2008, S. 47-71.

16 Fast alle Zeitschriften hatten eine Rubrik „Correspondence“, die meist aber nicht die Zuschriften der Leser abdruckte, sondern nur kurze Antworten hierauf.

17 BOM, Januar 1855, o. S.

$18 \mathrm{Vgl}$. The Art of Composition (The Editor's Letter to His Correspondents), in: EDM, Dezember 1852, S. 227. 
Im Folgenden wird es darum gehen, mit welchen diskursiven ,Profilen' in einzelnen Zeitschriften über Helden und das Heroische gesprochen wurde. Solche heroischen Profile sind durch eine Kombination von quantitativer und qualitativer Inhaltsanalyse oder, mit Franco Morettis Begriffen, ${ }^{19}$ eine Kombination von distant und close reading zu ermitteln. ${ }^{20}$ Meine Beispiele sind vier Zeitschriften mit unterschiedlichen Leserausrichtungen, die oben schon angesprochen wurden. Sie alle erschienen erstmals in den 1850er Jahren, hatten eine regelmäßig hohe Zirkulation und relativ lange Laufzeiten; man kann sie deshalb zu den einflussreichsten Veröffentlichungen in einem Medium zählen, das schon um die Jahrhundertmitte als populär erachtet wurde. ${ }^{21}$ Alle vier Zeitschriften suchten ihre Hauptleserschaften im Spektrum der Mittelschichten und in den gebildeten Teilen der Arbeiterschicht, was sich in einem relativ moderaten Preis pro Heft niederschlug:

1. „Boy’s Own Magazine“ (BOM, monatlich 1855-1869 zunächst zu 2 Pennies pro Heft, ab 1862 zum Preis von 6 Pennies, ab 1863 wöchentlich) war eine teils illustrierte Zeitschrift für Jungen bis zum Alter von etwa 16 oder 17 Jahren. Das Vorwort der ersten Ausgabe im Januar 1855 weist auf den Leserzuschnitt ausdrücklich hin: „The Boys' [sic] Own Magazine is commenced with the view of furnishing the numerous Youth of Great Britain with a periodical especially adapted to their reading."

2. „Englishwoman’s Domestic Magazine“ (EDM, monatlich 1852-1879 zu 6 Pennies pro Heft) war eine illustrierte Zeitschrift für die Frau. Wie das „Boy's Own Magazine“ wurde sie von Samuel Beeton verlegt.

19 F. Moretti, Distant Reading, London 2013.

20 Zur Ermittlung von Beispielen wurden in einem bei Zeitschriftenanalysen üblichen Verfahren in Intervallen (hier jeweils 5 Jahre im Zeitraum 1850-1900) Zeitschriften ausgewertet. Es wurden Texte ermittelt, in denen Wörter des Wortfeldes hero- vorkommen, allerdings bereinigt um die Zahl von Fällen, die ausschließlich den Protagonistenstatus in Romanen, Theaterstücken oder Opern bezeichnen. Es wurden also Fälle berücksichtigt, in denen auf heroische Figuren, Eigenschaften oder Verhaltensweisen Bezug genommen wird. Ein solches Verfahren erfasst nicht die Gänze von Texten, in denen Eigenschaften des Heroischen verhandelt werden, aber die Auswahl nach dem Wortfeld hero- gibt verlässliche Hinweise auf den zirkulierenden Heldendiskurs. Vgl. zur Methode auch den Artikel von S. Colella, 'That inscrutable something': Business in the Periodical Press, in: Victorian Periodicals Review 46, Heft 3, 2013, S. 317-342. Colella stellt hier unter Bezug auf Foucaults „Archäologie des Wissens“ unter anderem fest: „What flows, anonymously“ in the ,interstices of great discursive monuments', Foucault writes, is the spontaneous philosophy of those who did not philosophise'. [...] Digital archives of Victorian periodicals are the locus where ,habits of the lip" translated into print can be observed most efficiently", ebd., S. 317.

21 So der viktorianische Kritiker E. S. Dallas in seinem Artikel Popular Literature - the Periodical Press, in: Blackwood's Edinburgh Magazine, Januar 1859, S. 96-112, hier S. 101: „A periodical differs from a book in being calculated for rapid sale and for immediate effect. [...] It is necessary, therefore, to the success of a periodical, that it should attain an instant popularity - in other words, that it should be calculated for the appreciation, not of a few, but of the many. Periodical literature is essentially a popular literature." 
3. Die „Leisure Hour“ (LH, ab 1852 wöchentlich für 1 Penny pro Heft, ab 1880 monatlich für 6 Pennies, bis 1905) war eine besonders attraktiv illustrierte Zeitschrift, die zunächst zu einem sehr niedrigen Preis verkauft wurde, um ärmere Leser von billigen Sensationsblättern, den sogenannten penny dreadfuls, wegzulocken. Sie richtete sich an das generationen- und geschlechtsübergreifende Publikum der Familie, wie ihr Untertitel deutlich signalisierte: „A Family Journal of Instruction and Recreation". Hinter der Zeitschrift stand die einflussreiche Religious Tract Society, die sich der Verbreitung christlicher Werte verpflichtet hatte.

4. Säkular ausgerichtet war dagegen die von Charles Dickens gegründete und maßgeblich gestaltete „Household Words“ (1850-59, wöchentlich für 2 Pennies pro Heft). Dickens setzte diese Familienzeitschrift unter dem Titel „All the Year Round" mit leicht verändertem Konzept fort (sie bestand bis 1895). Beide Zeitschriften waren nicht illustriert, um sie möglichst preiswert zu halten, aber Dickens, dem Popularität bei seinen Lesern ein besonderes Anliegen war, kompensierte den Mangel an Illustrationen durch eine lebendige und unterhaltsame Schreibweise, die er allen Autoren seiner Zeitschriften abverlangte. ${ }^{22}$

In den heroischen Profilen dieser Zeitschriften zeigen sich viele Gemeinsamkeiten. Alle nennen als Helden Militärführer wie Nelson und Wellington, große Entdecker wie Kolumbus, aber auch Wohltäter wie den Gefängnisreformer John Howard. Auch dem zeitgenössischen Kult um den Freiheitshelden Garibaldi konnten sich alle Blätter anschließen. Überall erkennt man eine Wertschätzung von zivilem und vor allem ,moralischem ${ }^{6}$ Heldentum, ${ }^{23}$ die mit einer erweiterten sozialen Reichweite für Zuschreibungen heroischer Eigenschaften einhergeht. Neben diesen generellen Tendenzen zeigen sich in den Profilen der einzelnen Zeitschriften jedoch charakteristische Differenzen.

\section{Heroische Profile für verschiedene Teilpublika}

Das „Boy’s Own Magazine“ hat eine besonders hohe Frequenz einschlägiger Artikel. Nicht nur in biographischen und historiographischen Artikeln, in Erzählungen und Gedichten beschäftigten sich die jungen Leser mit Heroischem, sondern auch in Rätseln und bei Essaywettbewerben. ${ }^{24}$ Angesichts der Bedeutung, die die Ver-

22 Für weitere Angaben zu den Zeitschriften siehe L. Brake / M. Demoor (Hrsg.), Dictionary of Nineteenth-Century Journalism in Great Britain and Ireland, Gent 2009.

23 Die Bezeichnung ,moral heroism ' begegnet in vielen Publikationen der viktorianischen Zeit und bezieht sich auf eine heroische Haltung, die sich durch Charakterstärke und Altruismus auszeichnet, so etwa in einem Buch für Kinder: C. Lucas Balfour, Moral Heroism: or, The Trials and Triumphs of the Great and Good, London 1846.

241864 erschien ein hochwertig (mit Goldprägung und Goldschnitt) ausgestattetes Buch mit „Prize Papers Written on Various Subjects for the Boy's Own Magazine“ (London: S. O. Beeton). Es enthielt alle Preisessays für das Jahr 1863, unter anderem An Essay on the Ancient Greek Heroes, in: Prize Papers Written on Various Subjects for the Boy's Own Maga- 
mittlung von Leitbildern gerade in der Erziehung von Kindern hat, ${ }^{25}$ überrascht dies nicht. Ebenso wenig überraschend ist angesichts des exklusiv männlich konzipierten Publikums dieser Zeitschrift, dass sie das Heroische - mit wenigen Ausnahmen wie Garibaldis erster Ehefrau ${ }^{26}$ - vor allem als Ideal maskulinen Verhaltens präsentierte. Das erste Herausgeberwort (im Januar 1855) verkündete programmatisch:

„[...] feminine accomplishments [...] are to ,boys' entirely useless, if not distasteful. The pages of the Boys' [sic] Own Magazine will avoid naturally all these subjects [...]. Tales of Adventure, Stories of Heroism and Courage, will be recited, which will arouse feelings of ardent admiration for all that is good and noble."

Beispielen heroischer Aktion und imperialer Männlichkeit ${ }^{27}$ begegneten die jungen Leser in der Geschichte der großen Entdeckungen und der Eroberung 28 ebenso wie in Abenteuerromanen, ${ }^{29}$ deren Protagonisten oft selbst Heranwachsende waren und den Lesern so ein besonderes Identifikationspotenzial boten. ${ }^{30}$ Da das unter Königin Viktoria expandierende Empire zu Konflikten reichlich

zine, London 1864, S. 51-68, des 16-jährigen W. L. Barnes aus Winchester, der das antike Heldentum klar von den Eigenschaften eines modernen Heldentums abgrenzt, das ihm seine Zeitschrift als vorbildlich präsentierte: „It possessed no such qualities as generosity, justice, a sense of right, honesty, etc.; but bravery, strength, daring, and power were some of its principal attributes. Some of the very acts which gained them the name of hero were deeds of violence, plunder, and piracy. Such was heroism among the early Greeks. As, however, time passed on, laws were enacted and customs and morals became more refined, then also heroism assumed some of the softer qualities which were before unknown to it. Still heroism among a heathen nation, however civilized, must be a very different thing from heroism among a Christian nation, and we must limit our ideas of that quality and bear in mind that the ancients had not the same advantages as we have", ebd., S. 61.

25 Vgl. etwa P. Hunt, An Introduction to Children's Literature, Oxford 1994, S. 3; K. LesnikOberstein, Defining Children's Literature and Childhood, in: P. Hunt / S. G. Ray (Hrsg.), International Companion Encyclopaedia of Children's Literature, London 1996, S. 17-31.

26 Vgl. A Hero's Son, in: BOM, Mai 1861, S. 199-202. Der Titel des Artikels spielt sogar mit Erwartungen der jungen Leser, dass Helden Männer sind, denn Garibaldis Gattin wird hier im Titel nicht als Ehefrau eines Helden oder Mutter seines ebenso heroischen Sohnes vorgestellt, sondern selbst als Heldin, die nicht nur als ,a marvel of kindliness, courage, and devotion“, ebd., S. 200, galt, sondern auch mit der Muskete „heroic bearing“, ebd., S. 201, bewies.

$27 \mathrm{Vgl}$. etwa G. Dawson, Soldier Heroes: British Adventure, Empire and the Imagining of Masculinities, London 1994.

28 Vgl. etwa "Cortez and the Conquest of Mexico“ (serialisiert zwischen Februar und Dezember 1855).

29 Diese Romane vermittelten Vorstellungen einer Maskulinität, die sich in verschiedenen imperialen Aktionsfeldern mit Mut, Autorität, Durchhaltevermögen, Pflichtbewusstsein etc. bewähren konnte. Vgl. zum weiteren Kontext neben Dawsons Studie (Dawson, Soldier Heroes [Anm. 27]) auch K. Boyd, Manliness and the Boys' Story Paper in Britain: A Cultural History 1855-1940, Basingstoke 2003; J. M. MacKenzie, Heroic Myths of Empire, in: J. M. MacKenzie, Popular Imperialism and the Military 1850-1950, Manchester 1992, S. 109-137; J. Richards (Hrsg.), Imperialism and Juvenile Literature, Manchester 1989.

30 Solche Identifikationsmöglichkeiten bestanden auch im Fall der regelmäßig serialisierten Schulgeschichten, in denen vorbildliche Eigenschaften weniger in Abenteuerlust und außerordentlicher Tapferkeit lokalisiert wurden als in Verhaltensmustern, die der Lebenswirklichkeit der jungen Leser näher standen, wie Loyalität, Fairness, aber auch Sportlichkeit. 
Anlass bot, ist im „Boy’s Own Magazine“ auch militärisches Heldentum hoch präsent, von den Thermopylen bis zum Krimkrieg und der Indischen Rebellion von 1857. Eine lange Artikelserie stellte Träger des seit 1856 von der Königin für Tapferkeit (valour) verliehenen Victoria Cross vor; ${ }^{31}$ ihr Autor ist als „an Army Chaplain“ ausgewiesen, was erklären mag, warum die Artikel bei aller Würdigung soldatischer Taten nicht kriegsverherrlichend sind. ${ }^{32}$ Der Krimkrieg weckte aber auch generell humanitäres Interesse, und das Bild vom zivilisierten und menschlichen Soldaten wurde verstärkt in den Medien verbreitet. Ein Artikel betont ausdrücklich, dass Tapferkeit, die mit Menschlichkeit einhergeht, höher zu bewerten sei als tollkühnes Verhalten:

„It is ever gratifying to be able to record the deeds of brave men who for the honour of their country have risked their lives, without thought of self. It is, however, a still more agreeable task to perform when, in addition to the mere act of daring, we have to speak of kindly and humane feelings, which indicate higher and more noble sentiments on the part of the individual than the mere bull-dog courage which is more frequently found." 33

Der gleiche Artikel hebt hervor, dass das Victoria Cross auch an einfache Soldaten und sogar Zivilisten verliehen wird, das heißt, die erweiterte soziale Reichweite des Heroischen und seine Übertragung in nichtmilitärische Aktionsfelder wird explizit angesprochen:

„To become distinguished for deeds of bravery, or to gain such a prize as the Victoria Cross, is now within the reach of every individual, for, as we have here shown, the honour is conferred where it is deserved, whether the individual who has won it be soldier or civilian, and thus many of our readers who may have no intention of joining the army may yet be placed in such situations as to call from them acts of courage and daring which will gain them the highest distinction, and the one most coveted by the modern soldier." ${ }^{\text {"34 }}$

Die Leser des „Boy’s Own Magazine“ sollten vom Soldatentum allerdings auch nicht abgeschreckt werden. Ein Artikel über die Ausbildung von Kadetten auf einem Schulschiff räumt sogar ausdrücklich ein, dass die Lektüre von Heldenerzählungen, wie sie die Zeitschrift selbst anbot, sogar den Anstoß geben kann, der Marine beizutreten:

31 Zur Geschichte dieses Ordens und seiner Bedeutung für Vorstellungen des Heroischen in Großbritannien siehe M. C. Smith, Awarded for Valour: A History of the Victoria Cross and the Evolution of British Heroism, Basingstoke 2008.

32 Es kann auch dem Eindruck der öffentlich diskutierten und vielfach repräsentierten Opfer des Krimkrieges geschuldet sein, dass schon der erste Artikel der Serie die Kosten des Krieges - Tod, körperliche und psychische Verletzung - betont und das Ertragen von Leid als ebenso heroisch definiert wie die militärische Tat: „We write all this knowing that English boys feel deep sympathy with and have found admiration for, our soldiers, and to show that their powers of endurance, when disabled, equal in heroic worth their gallantry upon the field", Soldiers and the Victoria Cross, in: BOM, Oktober 1863, S. 308-316, hier S. 312-313. Auch wird hier betont, dass einfache Soldaten ebenso tapfer waren wie Offiziere, und dass selbst Frauen im Tross und in Hospitälern heroische Eigenschaften bewiesen.

R. L. Mangles, Esq., and the Victoria Cross, in: BOM, Juli 1864, S. 16-20, hier S. 18.

34 Ebd., S. 20. 
„There can be but few boys who have read any of the stirring stories of the enterprise and gallant deeds of British sailors, that abound in history and fiction, without feeling the glow of a latent desire to emulate their glorious acts of bravery and heroism awakening within them, warming the heart with an ardent longing to encounter the ,dangers of the seas,' and share the laurels that may be gleaned from the boundless fields of the salt sea waves. " 35

Der Artikel betont dann jedoch, indem er die sorgfältige Ausbildung der Kadetten schildert, dass Abenteuerlust nicht genügt, und die begleitende Illustration zeigt die jungen Kadetten entsprechend als aufmerksame Schüler, ${ }^{36}$ die auf einen Beruf vorbereitet werden und in dieser Hinsicht an der Seite der Helden der Zivilisierung und des Fortschritts stehen, die die Zeitschrift ebenfalls in großer Zahl vorstellte.

Das heroische Profil des „Boy’s Own Magazine“ ist insgesamt stark auf Nachabmung angelegt. So wird nie nur die Bedeutung und Größe heroischer Figuren herausgestellt, sondern immer auch die Werte, die sie verkörpern, denn es sind Werte wie Mut, Durchhaltevermögen, Tapferkeit, Sorge um das Wohlergehen anderer, die die Leser übernehmen sollen, auch in alltäglichen Lebensumständen. In diesem Sinne wird etwa für Kolumbus ausdrücklich festgehalten: „It is not [...] in the spirit of adventure [...] that we see the true greatness of the man." Seine Größe wird stattdessen in den folgenden „privaten“ und „öffentlichen“ Eigenschaften lokalisiert:

„The private character of Columbus was marked by piety and gentleness, whilst in his public career he was, as we have seen, patient in adversity, persevering amid discouragements, and dignified in the midst of success and applause. [...] How true it is that, in the most adverse circumstances of life, success is mainly dependent upon patience, and the continuance of manly effort! He that has a good end in view should never abandon it. He may often be foiled; but, with constancy and courage, the chances are that he will conquer yet." 37

Ähnlich geht ein Artikel über den Erfinder und Eisenbahnpionier George Stephenson vor, der sich aus einfachsten Verhältnissen emporgearbeitet hatte und ein Vorzeigeheld Smilesscher Selbsthilfe war. Stephensons Heldentum im Dienst des Fortschritts wird zunächst ausdrücklich vom scheinbar glanzvolleren des militärischen Heroismus abgesetzt:

„Now, boys, you would not, perhaps, guess the name of our hero, if we would allow you one half hour to do it in; for would not your mind be wandering over the great men who fought against Napoleon in the fierce European struggle - in that contest of giants dating from the siege of Toulon to the battle of Waterloo? [...] The honoured sound of Nelson would be heard, and Arthur Wellesley pronounced. It is, however, none of these; for there are other kinds of greatness besides that which we call war greatness -

35 F. Y., The Boys at the Big Guns, in: BOM, Januar 1863, S. 63-66, hier S. 63.

36 Ebd., S. 65.

37 Christopher Columbus, in: BOM, Juni 1855, S. 163-165, hier S. 163. 
there is other heroism besides that in the field, great and honourable as that is, too. [...] But our ,hero of the iron horse' $[\ldots]$ and his exploits were, the building of the first locomotive engine and the construction of the first railway in Great Britain. How our hero came to do this was through perseverance of the very highest order. ${ }^{\text {" } 38}$

Stephensons Heroismus erweist sich laut der Darstellung des Artikels in der Tat vor allem in Durchhaltevermögen und dem Aushalten von Widerständen: „Perseverance in spite of poverty, in spite of ignorance, and in spite of all the difficulties with which the great and wealthy surrounded him. ${ }^{\text {"39 }}$ Der Entdecker der Renaissance und der Erfinder des 19. Jahrhunderts werden also für die Leser des „Boy's Own Magazine“ mit den gleichen heroischen Charaktereigenschaften gezeichnet, und es sind diese Eigenschaften, die die Leser sich aneignen sollen. Um solche Adaption anzuregen, wurden den jungen Lesern immer wieder auch ,echte' Kinderhelden vorgestellt, wie ein holländischer Junge, der sein Dorf rettete, indem er bis zur Erschöpfung mit seinem Finger einen Deich abdichtete, ${ }^{40}$ oder Jungen, die sich in militärischen Konflikten - vor allem in ehrenhaften Kämpfen um Freiheit und Befreiung - trotz ihrer Jugend tapfer verhielten. ${ }^{41}$

Dass das Heldenverständnis ihrer ,eigenen' Zeitschrift die jungen Leser tatsächlich prägte, kann man Beispielen wie dem Preisessay zum Thema „True Courage" entnehmen, dessen Autor für seine Ausführungen mit einem silbernen Schreibetui belohnt wurde. Er hat offensichtlich den Heldendiskurs seiner Zeitschrift internalisiert und schreibt ihn mit ausdrücklichem Verweis auf den kleinen holländischen Jungen fort: „The power of endurance, the venture of life for the salvation of others, and obedience to duty under the most trying circumstances, are much higher manifestations of true courage than that displayed in the field." Am Ende betont er nochmals:

„We are not, then, to look only to the battle-field in search of true courage? Clearly no! nor [sic] to any one rank or condition in life. Whoever does his duty manfully and firmly, overcomes obstacles placed in his legitimate path with perseverance and resolu-

38 The Hero of the Iron Horse [Part I], in: BOM, November 1857, S. 325-331, hier S. 326.

39 Ebd., S. 326.

40 The Little Dutch Hero, in: BOM, Oktober 1855, S. 292-293.

41 Der Artikel Kit Snyder: The American Boy-Patriot, in: BOM, April 1857, S. 114-118, porträtiert den Jungen, der das erste Opfer der Boston Tea Party wurde: „the first martyr in the cause of American liberty", ebd., S. 118. In dem Artikel The Linden Tree of Fribourg: A Story of Heroism, in: BOM, Juli 1857, S. 193-197, wird eine Episode aus dem Schweizer Freiheitskampf geschildert: Ein junger verwundeter Mann riskiert sein Leben, um der Stadt Fribourg den Sieg über die Burgunder zu verkünden. Aus dem Lindenzweig, den er in seiner Hand hält, wächst später ein großer Baum, der an seine Tat erinnert: „this tree - calm, grand, and beautiful, a grateful shade, and an object of admiration - became, as it were, a part of history, a corroborative proof, a living witness, a page glowing and immortal, a green and leafy chronicle of what was, in Swiss history, an heroic age. It was, also, a coronal for him who had fought and bled, and who died with the glorious tidings upon his lips", ebd., S. 194. Der junge Soldat ist für die Bürger seiner Stadt, die ihn von ihrer Mauer anlaufen sehen, „their hero, who was henceforth to become a model for their future youth“, ebd., S. 197. 
tion, and sustains misfortune and defeat with calm and dignified fortitude, displays that glorious attribute which belongs alone to mind, and which we call TRUE COURAGE. “42

Der Heldenrezipient der Zeitschrift wird hier selbst zum Heldenproduzenten.

Da das „Boy’s Own Magazine“ zur Nachahmung heroischer Eigenschaften auffordern wollte, war es einem Gestus der Heldenberwunderung nicht abgeneigt. ${ }^{43}$ Heldenverehrung dagegen wird oft eine Absage erteilt. So wird unter den Einsendungen zu einem Essaywettbewerb über den niederländischen Prinzen Moritz von Nassau vor allem ein Essay gelobt, der auch die dunklen Seiten des Prinzen betont und so von naiver Verehrung absieht. ${ }^{44}$ Ein Artikel über den wegen militärischen Versagens 1757 exekutierten Admiral Byng mahnt, dass Versuche, den Admiral nachträglich wieder zu heroisieren, kritisch zu hinterfragen seien, denn dieser habe ja in Hinblick auf bestimmte Eigenschaften, vor allem Entscheidungskraft, deutliche Defizite an den Tag gelegt:

„[W]e have no sympathy with the maudlin philanthropy that seeks to make a hero and a martyr out of a British admiral who failed to do his duty. Want of energy and decision is as gross a crime in a commander as physical cowardice; and he who jeopardises the honour of his nation and the safety of his country's armies by infirmity of purpose is hardly entitled to the lenient judgement of posterity." 45

Keinesfalls sollten die jungen Leser selbst zu Heldenposen animiert werden, insbesondere nicht die der unteren Schichten: In einem Artikel über einen Reinlichkeitswettbewerb in einer Fabrik, der mit einer Fotografie des Gewinners belohnt wurde, wird ausdrücklich festgehalten, dass das erste Foto eines Gewinners ausge-

True Courage, in: BOM, September 1858, S. 268-271, hier S. 269 und S. 270-271.

Vgl. genauer den interdisziplinären Literaturbericht von I. Schindler [et al.], Admiration and Adoration: Their Different Ways of Showing and Shaping Who We Are, in: Cognition and Emotion 27, Heft 1, 2013, S. 85-118. Unter anderem muss im Fall von Bewunderung der Bewunderer dem Bewunderten in einzelnen Eigenschaften folgen können: „Admiration results when the individual recognises one or a few concrete values of personal significance in the other, such as altruism, competence, courage, or tenacity. [...] Admiration thereby often responds to a specific action or outcome of the other rather than the other as an entire person“, ebd., S. 99. In diesem Sinne spezifizieren auch die Artikel über nachahmenswerte Helden in den viktorianischen Zeitschriften fast immer spezifische Eigenschaften von Helden.

„[W] hile awarding to Maurice his just need of praise as the most consummate warrior of his age, they do not fail to recognise the darker side of his character, nor to point out those blemishes as a ruler which tarnished his fair fame as a soldier." Der Zweitplatzierte wird in dieser Hinsicht besonders gelobt: „He is no ,whole hog' hero-worshipper, and when Maurice goes wrong, Master Lewis is down on him for not playing fair", Prize Papers for the Boy's Own Magazine: Prince Maurice of Nassau, in: BOM, Juni 1865, o. S. Dieser Beitrag findet sich in dem unpaginierten Teil, in dem üblicherweise die Werbung und Korrespondenz mit den Lesern veröffentlicht wurde. Er wurde bei einer Bindung der Hefte zu einem Band normalerweise entfernt, ist in einigen Exemplaren der Zeitschrift aber glücklicherweise erhalten.

W. H. Davenport, The Story of Admiral Byng, in: BOM, Oktober 1864, S. 343-349, hier S. 348 . 
tauscht werden musste, weil er zu heroisch posiert hatte, und das Foto daher dem darzustellenden Ideal von „honourable toil“ widersprach. ${ }^{46}$ Ein weiterer Artikel setzt sich kritisch mit den von Jungen gerne gelesenen penny dreadfuls auseinander. Die Kritik richtet sich nicht nur gegen die billige Qualität und den Sensationalismus dieser Publikationen (,modern cheap-and-nasty-romance“), sondern vor allem die Tatsache, dass hier oft Kriminelle heroisiert wurden, wie der Straßenräuber Jack Sheppard, der 1724 mit nur 22 Jahren gehängt wurde. Dagegen setzt der Artikel eine gezielte Deheroisierung Sheppards und schließt mit einem Appell an die jungen Leser:

„For pity sake, boys, let the poor dead and buried felon rest, and when an attempt is made to set his dishonoured bones before you ,in a cheap and attractive form, ' let not the gaudy paint and tinsel with which the tap-room author decorates them attract you or gull you out of a single penny. “47

Abgesehen von solchen Wertungen, die richtige von falschen Helden klar unterscheiden, lässt sich das „Boy’s Own Magazine“ grundsätzlich als Zeitschrift charakterisieren, in der heroische Figuren und Ideale prominent und affirmierend präsentiert wurden, um den jungen Lesern nachstrebenswerte Vorbilder aufzuzeigen.

Ambivalenter und zurückhaltender ist das heroische Profil des vom gleichen Verleger herausgebrachten „Englishwoman's Domestic Magazine“. Diese Publikation war Teil eines neuen Booms von Frauenzeitschriften für die Mittelschichten. Sie verortete Weiblichkeit vor allem im Rahmen des Privaten und Häuslichen, ${ }^{48}$ unterstützte allerdings auch zeitgenössische Forderungen nach Frauenrechten. ${ }^{49}$ Den kulturellen und gesellschaftlichen Leistungen von Frauen zollte das „Englishwoman's Domestic Magazine" wie andere Frauenzeitschriften in zahlreichen biographischen Essays Tribut. Insofern kompensierten die Frauenzeitschriften die Tatsache, dass weder Carlyle noch Smiles in ihren einflussreichen Schriften weiblichen Leit- und Vorbildern nennenswerte Beachtung schenkten. Auffällig ist aber, dass diese biographischen Artikel, auch wenn sie oft die Entschlossenheit, den Mut und die Führungskompetenz von Frauen erwähnen, diese Frauen eher selten explizit als ,heroisch' bezeichnen. ${ }^{50}$ Allgemein war die zeitgenössische Kopplung von Heroizi-

46 C. Burroughs, Photography in the Factory: A Tale of a White Devil, in: BOM, Januar 1861, S. 36-41, hier S. 40.

47 A True Account of the Rascally Jack Sheppard, in: BOM, April 1869, S. 216-220, hier S. 220.

48 Vgl. R. Ballaster [et al.], Women's Worlds: Ideology, Femininity, and the Woman's Magazine, Basingstoke 1991, S. 88.

49 Beetham stellt daher fest: „The extraordinary diversity of genres and voices which characterized the EDM allowed very different models of femininity to co-exist on its pages", Beetham, A Magazine of Her Own? (Anm. 8), S. 61.

50 So charakterisieren die „Historical Female Biographies“ von Agnes Strickland Mary Stuart als „endued with the noble and heroic qualities of a great mind“, A. Strickland, Historical Female Biographies: Mary Stuart, in: EDM, August 1862, S. 171-180, hier S. 173, und schreiben über Madame Roland: „We only see Madame Roland, wise, earnest, selfcontained, courageous, industrious, fruitful in resource, equal to emergency, and various as 
tät, Maskulinität und öffentlicher Aktion zu stark, als dass sie sich reibungslos auf Frauen - selbst exzeptionelle Frauen - übertragen lassen konnte.

Aber auch generell erweist sich das „Englishwoman’s Domestic Magazine“ bei der Darstellung von Heldentum reserviert. Explizite Verweise auf Heroisches sind deutlich seltener als im „Boy’s Own Magazine“, und sie finden sich oft nur als kürzere Erwähnungen in Artikeln zu anderen Themen. Soldatisches Heldentum spielt, nicht überraschend für eine Frauenzeitschrift, eine untergeordnete Rolle. Eine der emphatischsten Würdigungen des Heroischen findet sich bezeichnenderweise in einem Gedicht zu Ehren eines zivilen Helden, des Feuerwehrmanns James Ford, der bei der Rettung einer Frau und ihres Kindes ums Leben gekommen war. ${ }^{51}$

Häufiger wird im „Englishwoman’s Domestic Magazine“ eine Diskrepanz zwischen romantischen Vorstellungen über ,Helden' und der Wirklichkeit festgestellt vor allem mit Bezug auf Mädchen und junge Frauen, und interessanterweise vor allem innerhalb serialisierter Romane, also einer Gattung, der vorgeworfen wurde, vor allem bei Leserinnen weltfremde Fantasien zu erzeugen. ${ }^{52}$ So müssen mehrere Protagonistinnen von Romanen die Erfahrung machen, dass ihre durch Fiktion genährten Vorstellungen heroischer Maskulinität von den Männern, die sie heiraten wollen oder müssen, nicht erfüllt werden. Die Titelfigur des Romans „Christian Hazell's Married Life“ klagt zum Beispiel am Vorabend ihrer Hochzeit: „I always fancied I should like a person with something great, something heroic, about him, like the Chevalier Bayard, or - John Howard, or George Washington. Now Alick seems so different. “" ${ }^{33}$ Und die Protagonistin des Romans „The Saviles“, „much given to hero worship“, sieht der Ehe mit einem Mann entgegen, den sie „prosaic in the extreme" findet. ${ }^{54}$

Zum „Englishwoman’s Domestic Magazine“ lässt sich resümieren, dass die Zeitschrift heroische Eigenschaften unter bestimmten Umständen positiv darstellte, vor allem dort, wo Menschen ihre Pflicht taten, egal in welchem Aktionsfeld. Im Vergleich zur Zeitschrift für Jungen ist die Einstellung gegenüber dem

the sternest demands of every hour - the grand heroine of the Revolution", A. Strickland, Historical Female Biographies: Madame Roland, in: EDM, Juni 1872, S. 329-334, hier S. 332. Der Artikel betont zudem, wie tapfer Roland zum Schafott schritt - im Gegensatz zu einem männlichen Hinzurichtenden: „Lamarque excited her pity by his unmanly fears“, ebd., S. 333. In einem Artikel über „Woman’s Rights“ werden heroische Herrscherinnen wie Semiramis und Zenobia erwähnt: EDM, 1. Juni 1872, S. 349-350.

51 Fire! Fire! Fire!, in: EDM, Januar 1872, S. 55.

52 Ein Beitrag des Herausgebers in der Rubrik „A Woman's World of Thought“ räumt ein, dass die Literatur auch positive und nachstrebenswerte Helden zu bieten habe, wie etwa die Romane von Sir Walter Scott: The Example of Fiction, in: EDM, Mai 1877, S. 246-247.

Christian Hazell's Married Life, in: EDM, Januar 1877, S. 4.

54 The Saviles, in: EDM, Oktober 1872, S. 185, S. 190. Dass hero-worship auch bei Männern zur Desillusion führen kann, spricht ein Artikel über Beethoven und seine enttäuschte Napoleon-Verehrung aus: Beethoven: His Life, His Works, and Their Interpreters, in: EDM, Oktober 1867, S. 530-534, hier S. 531. 
Heroischen aber zurückhaltender und skeptischer. Wie in dieser Frauenzeitschrift wird auch in den Familienzeitschriften oft nur beiläufig auf Helden verwiesen, zum Beispiel in Berichten über Reisen oder in topographischen Texten, in denen Denkmäler oder Gräber heroischer Figuren beschrieben werden. Auch bei dieser Art von Zeitschrift sind Artikel, die explizit dem Heroischen gewidmet sind, seltener als im „Boy’s Own Magazine“. Gleichwohl lässt es das Material zu, zwischen der „Leisure Hour“ und den von Dickens herausgegebenen Zeitschriften abweichende Profile des Heroischen festzustellen.

Die christliche „Leisure Hour“ bekannte sich grundsätzlich zur Bedeutung von Helden und Heiligen für die Stiftung nationaler Identität, zum Beispiel in einem Artikel über Bibellektionen für das Alltagsleben:

„A nation, a whole nation, is raised and blessed by its heroes and saints. They give it a character by their own virtue, and largely help their fellows to be better than they would have been without their example and influence. The great men of a people bring, moreover, a blessing on that people, directly and indirectly. Now although a man may not be so gifted as to become conspicuous for the wholesome effect he has upon mankind, or upon a particular nation, every one can contribute something, and so far bring about that general good state which all desire. ${ }^{\text {"55 }}$

Dass die „Leisure Hour" Heldenfiguren gezielt als nachstrebenswerte Vorbilder für ihre Leser präsentierte, kann man auch einer Annonce entnehmen, mit der die Zeitschrift wiederholt auf eine Buchpublikation ihrer Trägerin, der Religious Tract Society, hinwies: „British Heroes and Worthies“. ${ }^{56}$ Mit dieser Absicht präsentierte sie - neben einem charakteristischen Augenmerk auf religiöse Helden ${ }^{57}$ - wie das „Boy’s Own Magazine“ Heldenfiguren verschiedener Provenienz: Militärführer, einfache Soldaten und Seeleute, Entdecker, Helden der Zivilisierung und des Fortschritts (Ingenieure, Wissenschaftler) sowie Lebensretter. ${ }^{58}$ Da das Heldenbild der „Leisure Hour“ jedoch in besonders hohem Maße religiös imprägniert war, wird an der Verehrung von Helden auch besondere Kritik geübt, denn worship sei schließlich Gott vorbehalten: „Every other species of man-worship is a robbery of him“, heißt es in einer Notiz über „Hero Worship“. ${ }^{59}$ Selbst im Nachruf auf den großen Nati-

55 Bible Lessons for Every-Day Life, in: LH, 25. September 1880, S. 614-615, hier S. 614.

56 British Heroes and Worthies, With Portraits, London 1871. Das Buch war mit Goldprägung und Goldschnitt wertvoll aufgemacht. Präsentiert werden Bildporträts und Biografien unter anderem von Wycliffe, John Knox, Lady Jane Grey, John Foxe, Sir Philip Sidney, Sir Walter Raleigh, William Harvey, John Milton, Andrew Marvell und Sir Christopher Wren.

57 Siehe etwa Bible Lessons for Everyday Life (Anm. 55). Der Artikel „Visit to the Plymouth Breakwater" ist ein Reisebericht, in dem die Pilgrim Fathers als „heroes of religious freedom" bezeichnet werden, Visit to the Plymouth Breakwater, in: LH, 18. März 1852, S. 177-181, hier S. 178.

58 The Vanguard of Progress, in: LH, 8. Januar 1852, S. 26-28; Science in Humble Life, in: LH, 1. Mai 1875, S. 277-280; Livingstone's Heroic Spirit of Duty (in der Rubrik „Varieties“), in: LH, 27. März 1875, S. 208.

59 H. Miller, Hero Worship (in der Rubrik „Varieties“), in: LH, 3. Mai 1860, S. 436. 
onalhelden Wellington greift dieses Tabu der Verehrung menschlicher Helden, und Wellington wird so ausdrücklich als Instrument Gottes präsentiert:

„We are not hero-worshippers ourselves, and of all so-called heroes we have the least predilection for mere warriors. War, for its own sake, would be a despicable thing, even were it not a horrible and soul-destroying thing. But God sends his judgments upon the earth in the shape of wars, as well as of earthquakes and pestilences. [...] True patriots and true heroes are often his instruments in bringing this about. Such an instrument in the hand of God we have been in the habit of regarding the Duke of Wellington. To us he appears to have been specially trained by an overruling power. ${ }^{\text {"660 }}$

Der Wellington-Nachruf ist auch insofern für die „Leisure Hour“ charakteristisch, als sich hier eine noch stärkere Wertschätzung für moral heroism artikuliert als in anderen Zeitschriften. In der Tat ist es nur dieses moralische Heldentum ethischen Handelns und mentaler Festigkeit, das Wellington für die Leser überhaupt zugänglich macht, denn in seinen öffentlichen Taten ist er von den Lesern der Zeitschrift viel zu weit distanziert, als dass sie ihm nachstreben könnten:

„The triumphant commander, the arbiter of war, the stern senator, the counsellor of sovereigns - the iron Duke - stands too far aloof from our common sympathies. We claim a human relationship with the great departed, and in support of that claim we seek in his past deeds some touch of nature which ,makes the whole world kin."“61

Der Nachruf will also eine menschliche Beziehung zum großen Verstorbenen („a human relationship with the great departed") aufbauen und reduziert Wellington deshalb in Anekdoten auf eine Dimension, in der er auch gewöhnlichen Menschen ein nachahmbares Vorbild sein kann, etwa wenn er in Indien ein verwaistes Kind in seine Obhut nimmt oder wenn er um Tote in einer Schlacht trauert.

Generell ist die „Leisure Hour" eine große Verfechterin des moralischen Heldentums mit Werten wie Pflichtbewusstsein, Prinzipienfestigkeit, Zielstrebigkeit, mentaler Stärke und Opferbereitschaft, denn diese sind nicht nur mit der christlichen Ausrichtung der Zeitschrift kompatibel, sondern auch ihrem Selbstverständnis als klassenüberschreitende Publikation: „From the highest to the lowest, there is no circle from which we desire to exclude ourselves“, wie es im oben bereits zitierten allgemeinen Vorwort an den Leser heißt. ${ }^{62}$ Eigenschaften moralischen Heldentums kann jeder im eigenen Alltag beweisen, wie die Zeitschrift mit Beiträgen über

60 The Duke of Wellington, in: LH, 4. November 1852, S. 713-718, hier S. 718. Angesichts solcher Einschränkungen gegenüber Heldenverehrung verwundert es nicht, dass die Zeitschrift Carlyle kritisch gegenüberstand. Negativ wird Carlyle zum Beispiel in einem Artikel gezeichnet, der ihm eine arrogante Haltung gegenüber einem heroischen Bergarbeiter vorwirft: „Here was a case of ,manful, prompt, and salutary human heroism, ' according to Mr. Carlyle's own account, and yet he, the prophet of hero-worship, could sneer at it. Can the reader?“, Miners of Cornwall, in: LH, 9. Februar 1860, S. 91-95, hier S. 95.

61 The Duke of Wellington (Anm. 60), S. 716.

62 H. D., Word with our Readers (Anm. 13), S. 9. 
heroisches Verhalten einfacher Menschen zeigt, ${ }^{63}$ und auch in Beiträgen über heroische Frauen, denen zugestanden wird, in Ausnahmefällen ebenso tapfer agieren zu können wie Männer. ${ }^{64}$

Grundsätzlich war die Zeitschrift aber auf Geschlechterdifferenz bedacht. Ein Artikel über die Dichterin Felicia Hemans spricht aus, dass Frauen einen „higher heroism" als Männer verkörpern, ein Heldentum gesteigerter Moralität, das sich vor allem über Selbstverleugnung und Hingabe definiert und über die große öffentliche Tat erhebt:

„In these days of utilitarianism, it is not without its uses to show woman as she has been, and we venture to say, ever will be - capable of the loftiest actions of self-denial and devotion, imbued with the heart of the martyr, and the spirit of the hero. Wherever danger and death have been, in all ages and in all countries [...] there do we find the presence of woman as the ,falcon-hearted dove,' showing strength out of very weakness, courage out of very cowardice. ${ }^{\text {65 }}$

63 Vgl. Heroes in Humble Rank (in der Rubrik „Varieties“), in: LH, 12. Juli 1855, S. 448. Siehe auch das Gedicht The Plate-layer Hero, in: LH, Februar 1900, S. 361, über einen Eisenbahnarbeiter, der sich opfert, um ein vergessenes Werkzeug von den Schienen zu holen, bevor es einen Zug zum Entgleisen bringen kann. Es handelt sich um ein preisgekröntes Gedicht der Leserin Georgina Brown für das Leisure Hour Eistedfodd. Der kurze Artikel The Power of "Good Spirit" (in der Rubrik „Varieties"), in: LH, 22. Mai 1880, S. 336, beschreibt den Mut, mit dem Krankheit ertragen wird, und in der Serie „The Lessons of Biography: A Lecture for Working-Men“ heißt es im letzten Teil: „among the labouring and industrious classes [...] we have witnessed as many examples of real heroism and stern virtue as we have found in the most cultivated circles", The Lessons of Biography: A Lecture for Working-Men, in: LH, 29. Juli 1852, S. 485-506, hier S. 486.

64 So heißt es in einem Artikel über die Indische Rebellion von 1857: „men and women, soldiers and civilians, of all ranks in the revolted districts, swelled for the time to the dimensions of heroes", English Heroism in India, in: LH, 16. Februar 1860, S. 108-109, hier S. 109. Siehe auch einen Artikel über die Globetrotterin Ida Pfeiffer: ,a perfect heroine in foreign travel, undauntedly mingling with lawless tribes without an escort, penetrating the depth of woods, roaming the desert, exploring the terrible phenomena of volcanic sites, and accomplishing a journey round the globe", The Lady Traveller, in: LH, 29. Januar 1852, S. 69-72, hier S. 69. Beiträge über große Frauengestalten der Geschichte boten unter anderem die Serie Poccahontas, in: LH, 9. September 1852 bis 30. September 1852, sowie Artikel über Elisabeth von der Pfalz: Electress Palatine Elizabeth, in: LH, 3. Juli 1875, S. 427-431, und Johanna von Orleans: Birthplace of Joan of Arc, in: LH, 29. Juli 1876, S. 488-490.

65 Felicia Hemans, in: LH, 29. Januar 1852, S. 72-76, hier S. 72, S. 73. Vgl. in diesem Kontext auch E. Salmons Artikel What Girls Read, in: Nineteenth Century, Oktober 1886, S. 515529, der ebenfalls einen überlegenen, da zivilisierteren, Heroismus des weiblichen Geschlechts propagiert: „In the ranks of girls and women it may be conceded are centred the greatest heroism, the noblest devotion, the highest purpose, the longest suffering, the harshest and cruellest of human trials. [...] It is courage of the first order. The courage which makes a man face boldly an enemy on the field of battle or fling himself into the boiling surf to rescue a fellow-creature is, too, deserving of all honour, but it is, nevertheless, courage of a second order and is primarily man's. [...] It requires to face fever in a loathsome alley, or to minister to the needs of the wounded soldier, a courage dissimilar in all respects to that called forth by the necessity of spiking a gun or swimming out to a wreck. The one is devotion, human, spiritual, Christian; the other is pluck, animal-like in its character, desperate in its instincts. The former is noted by God and lauded by man, but requires an uncommon power to treat adequately from the point of view of the story 
Die Vorstellung eines nobleren weiblichen Heroismus steht im Einklang mit den dominanten Geschlechternormen der hochviktorianischen Epoche, die Frauen der Mittelschichten über häusliche und damit kompatible Tugenden und Aktivitäten definierten. Gleichwohl ist moralischer Heroismus ein Feld, in dem sich die fortschreitende Demokratisierung von Heroisierungsprozessen nicht nur auf der Klassen-, sondern auch der Geschlechterebene schon um die Mitte des 19. Jahrhunderts abzeichnet.

Ähnlich wie in den anderen betrachteten Zeitschriften wird auch in der „Leisure Hour" über das Heroische reflektiert und werden angemessene und unangemessene Heroisierungen unterschieden. So stellt ein Artikel über Robert Clive, einen wichtigen, aber umstrittenen Akteur der Kolonisierung Indiens, die Frage, ob Clive ein Denkmal verdiene; zwar war er der Sieger der Schlacht von Plassey (1757), aber auch für seine Korruption bekannt.66 Das Gedicht „War“ fragt ebenso kritisch, wie im Krieg zwischen Mördern und Helden unterschieden werden könne: „One murder makes a villain, Millions a hero“. ${ }^{67}$ Und auch die „Leisure Hour“ fragt, wie das „Boy’s Own Magazine“, ob man Räuberei, auch wenn sie der Umverteilung von Reichtümern dient, als Heldentat feiern dürfe. ${ }^{68}$

In Charles Dickens' Zeitschriften finden sich weniger Artikel mit prominenter Referenz auf das Heroische als in der „Leisure Hour“. Für Dickens, dem soziale Reformen in der Gegenwart ein zentrales Anliegen waren, hatte die englische Geschichte an heroischen Leitbildern wenig zu bieten, ${ }^{69}$ und auch für die Gegenwart wird heroisches Posieren lächerlich gemacht, zum Beispiel in dem Artikel „Heroes Afloat“, der Zivilisten beschreibt, die per Schiff in den Krimkrieg aufbrechen und sich dabei übertrieben martialisch gebärden. ${ }^{70}$

Allerdings finden sich in „Household Words“ und „All the Year Round“ einige Artikel, die heldenhaftes Verhalten in bestimmten Bereichen noch würdigen. Garibaldi als Freiheitsheld scheint jenseits aller Kritik, ${ }^{71}$ ebenso wie die heroischen Entdecker in der Arktis, die „Household Words“ in einer dramatischen Szene (zum Nachspielen) präsentierte. ${ }^{72}$ Auch moralischer Heroismus wird propagiert, etwa in einem „All the Year Round“-Artikel mit dem bezeichnenden Titel „A Simple Hero“. Er präsentiert einen Soldaten, der bei einer Choleraepidemie aufopferungsvoll Kameraden pflegt, bis er der Seuche selbst zum Opfer fällt:

reader; the latter is easily susceptible of a treatment, feverish and romantic, which may be expected to appeal to the dullest of imaginations. The gore of the battle-field and the flames of the burning building are facts more readily grasped by, and hence more interesting to, the majority of youthful readers than the sick room and injured heart", ebd., S. 516.

War, in: LH, 24. September 1870, S. 624.

Siehe den Artikel William Brodie, in: LH, 22. November 1855, S. 745-747.

In seiner „Child's History of England“, die zwischen 1851 und 1853 in HW serialisiert wurde, identifizierte Dickens kaum Helden der nationalen Geschichte.

Heroes Afloat, in: HW, 5. August 1854, S. 593-596.

To Nicæa, the Birthplace of Garibaldi, in: AYR, 17. Juli 1860, S. 324-325.

Arctic Heroes: A Fragment of Naval History, in: HW, 27. April 1850, S. 108-109. 
„There was nothing very remarkable or striking about him - he was only a private soldier in a line regiment - an orderly, or tender of the sick, in a regimental hospital." Nicht durch die große Kriegstat zeichnet sich dieser Soldat aus, sondern durch seinen selbstlosen humanitären Einsatz, der die Pflicht übersteigt: „And where all did their duty well and bravely, none was so fearless, none so untiring, so zealous for suffering comrades as my humble hero". ${ }^{73}$ Wie in den anderen betrachteten Zeitschriften ist also auch im Profil der Dickens-Zeitschriften eine Tendenz zur erweiterten sozialen Reichweite von Heldenzuschreibungen erkennbar, ebenso wie eine Erweiterung auf ziviles und humanitäres Heldentum.

Je nach intendierter Leserschaft, so lässt sich vorläufig resümieren, setzen viktorianische Zeitschriften bei der Darstellung und Bewertung des Heroischen unterschiedliche Akzente. Allerdings gibt es auch große Linien, die für ihre Epoche charakteristisch sind: Signifikant ist die Skepsis gegenüber unkritischer Heldenverehrung, während die Bewunderung für Helden, weil sie Nachahmung von Vorbildlichem befördert, sanktioniert war und besonders für junge Leser nachdrücklich ermutigt wurde. Die Wertschätzung für nachahmbares Heldentum zeigt sich auch in der Bedeutung, die alle Zeitschriften zivilem und speziell moralischem Heldentum zuschrieben. Gerade dieser Akzent passt in das Bild, das sich die Zeitschriften von ihrem Publikum machten, und zu der Funktion, die sie für diese Leser und Leserinnen erfüllen wollten, nämlich die Vermittlung gemeinschaftsstiftender Ideale und Werte. Nur wenige Leser und noch weniger Leserinnen der betrachteten Zeitschriften hätten Spielräume für heroische Aktion im militärischen Feld, als abenteuerliche Entdecker und Reisende, als herausragende Erfinder und Wissenschaftler oder als große Wohltäter gehabt. Im Alltagsleben und in einem kleineren Maßstab aber konnten sie Helden folgen, wenn deren als heroisch identifizierte Eigenschaften im weitesten Sinne Charaktereigenschaften und Merkmale ethischen Verhaltens waren. Für eine imitatio in diesem Sinne sollten Helden nicht im Carlyleschen Sinne verehrt werden, aber sie mussten weiterhin bereundert und entsprechend präsentiert werden, in „Tales of Adventure, Stories of Heroism and Courage [...] which will arouse feelings of ardent admiration for all that is good and noble", wie das „Boy's Own Magazine“ in seinem ersten Vorwort programmatisch formulierte. ${ }^{74}$ Berwunderung nämlich stiftet das affektive Band zwischen Helden und ihrer Interpretationsgemeinschaft, das zur Nachahmung animiert. Dessen waren sich die Produzenten und Autoren der Zeitschriften bewusst, und man stößt somit immer wieder auf Artikel, die die Bewunderung eines Publikums für einen Helden explizit thematisieren und sogar inszenieren. Ein Beispiel dafür soll abschließend eingehender untersucht werden.

73 A Simple Hero, in: AYR, 28. Oktober 1876, S. 147-149, hier S. 148.

74 BOM, Januar 1855, o. S. 


\section{Die Inszenierung der Bewounderung}

Mein Beispiel entstammt nicht zufällig einer der Zeitschriften von Dickens, der, wie erwähnt, ein für Publikumswirkung besonders sensibler Autor und Herausgeber war. Im Oktober 1859 veröffentlichte „All the Year Round“ einen von William Blanchard Jerrold verfassten (allerdings wie üblich anonym publizierten) Artikel mit dem Titel „The Conquering Heroes Come“ ${ }^{\text {" }}{ }^{75}$ Der Titel bezieht sich auf einen bekannten Chor aus Händels Oratorium „Judas Maccabeus“, welches Händel zu Ehren des bei der Schlacht von Culloden (1746) gegen die Jakobiten siegreichen Prinzen Wilhelm Augustus komponiert hatte: „See, the conquering hero comes! / Sound the trumpets, beat the drums". Im Artikel gefeiert werden aber Soldaten (und zwar auch der einfachen Ränge), die soeben in einem aktuellen Konflikt gekämpft haben, nämlich dem Krieg zwischen Frankreich und Österreich in Italien. Geschildert wird mit großem Detail und großer Lebendigkeit der Empfang, den die Stadt Paris und ihre Bürger der siegreichen Armee am 14. August des Jahres bereiteten. Der Text operiert dabei mit der Strategie, seinen Lesern ein intradiegetisches Publikum vorzustellen, dessen Reaktion auf Helden die Leser somit beobachten und gegebenenfalls zu sich selbst in Bezug setzen können: Der Triumphzug wird als Ereignis inszeniert, an dem nicht nur die heroischen Soldaten teilnehmen, sondern auch das sie bewundernde Publikum am Straßenrand. Die Sprache des Textes gibt die emotionale Erregung dieses Publikums und das überwältigende Spektakel der Truppen präsentisch und dynamisch wieder. Als die „Conquering Heroes“ endlich ihren Auftritt haben, hat sich die gespannte Erwartung der Menge auf den berichtenden Augenzeugen übertragen und wird in dieser überblendeten Perspektive auch den Lesern vermittelt. Die Darstellung ist ebenso sinnlich wie affektgeladen:

„Yes, yes, they are coming! Oh! moment of supreme happiness! Oh! proud mothers and sisters, and wives, throw open your arms - for your heroes, with lofty step, though footsore and elbow-greasy, are tramping along the triumphal way; and every step presses a votive flower! Bright helmets gleam through the dust, the music swells, and sharp is the roll of the drums. A loud, shrill prolongued cry greets this new assurance that the heroes are at hand. And then a dead silence follows. Every eye is searching a few yards behind the sturdy horsemen who open the march, searching for a solitary figure." 76

Dem nach der vorangegangenen Aufregung hier mit ehrfürchtigem Schweigen begegneten Heerführer folgen die von der Menge dann wieder bejubelten Verwundeten der Schlacht, und sogar einem mitgeführten Regimentshund scheint in der bewundernden Wahrnehmung Stolz auf die erbrachten Taten anzusehen zu sein: „And the dog marching before all Paris, with a decoration upon his proud canine chest, and his general military costume, is equal to his brilliant destiny." 77

75 The Conquering Heroes Come, in: AYR, 1. Oktober 1859, S. 541-546.

76 Ebd., S. 545.

77 Ebd. 
Erst ein Regenguss vermag der Bewunderung der Helden ein Ende zu setzen. Hier und an einigen anderen Stellen zeigt der Artikel eine leichte, wohlwollende Ironie angesichts der überbordenden Begeisterung für die Helden; aber auch der berichtende Augenzeuge wird letztlich von dieser Begeisterung angesteckt. Die Theatralik des Heldenempfangs wird von ihm gewürdigt und die emotionale Reaktion der Bewunderer nachvollziehbar gemacht. ${ }^{78}$

Artikel wie dieser erkannten an, dass es in der viktorianischen Öffentlichkeit neben Heldenskepsis auch noch ein Bedürfnis nach Helden gab, und sie signalisierten ihrem zeitgenössischen Publikum, dass Helden, so kritisch manche ,falschen' Heroisierungen auch gesehen wurden, weiter bewunderns- und sogar feiernswert waren - zumal die gemeinschaftliche Feier und geteilte Bewunderung (ob bei einem Publikum auf der Straße oder bei den Lesern einer Zeitschrift) eine Wertegemeinschaft stiften konnte. Das innertextliche Publikum in „The Conquering Heroes Come“ ist, wie die intendierten Leserschaften der betrachteten Zeitschriften, eine Masse, aber keine streikende oder gar revolutionäre und damit für die Gesellschaft prekäre, sondern eine in der Bewunderung für Helden geeinte ganz im Sinne der Funktion, die die Zeitschriften sich selbst in der Beziehung zu ihrem Publikum zuschrieben.

$*$

Publikumszeitschriften mussten in der viktorianischen Zeit wie heute Publikumsinteressen und -bedürfnisse bedienen, um auf einem kompetitiven Markt überleben zu können. Dass in den betrachteten Zeitschriften das Thema des Heroischen behandelt wurde, reagiert auf ein Interesse, das in der viktorianischen Kultur am Heroischen bestand und das sich auch in anderen Bereichen der kulturellen Produktion niederschlug. Die Zeitschriften reagierten aber nicht nur auf ein Interesse an Helden und bestehende Diskurse über das Heroische, sondern sie wirkten - als mediale ,Heldenmacher - an diesen Diskursen aktiv mit und prägten das Heldenverständnis ihrer Leser in unterschiedlicher Weise. Das Interesse der betrachteten Publikumszeitschriften am sozialen Zusammenhalt - ob der ganzen Nation oder der Gemeinschaft der eigenen Teilpublika - dürfte sie nicht nur für das Heldenthema disponiert haben. Es mag zudem erklären, warum der Blick dieser Zeitschriften auf das Heroische zwar vielfältig, aber nie kontrovers ist. Zwar sind die Zeitschriften auch mit ihren Heldenprofilen auf bestimmte Leserschaften zugeschnitten (mit besonders deutlichen Unterschieden zwischen der Knaben- und der Frauenzeitschrift), verfolgen dabei aber die gleichen übergeordneten Intentionen: Heldenfiguren und das Thema des Heroischen dienten in allen Zeitschriften als Projektionsfläche für die im politischen und kulturellen Erwartungshorizont der viktorianischen Gesellschaft angelegten und auf breiter Basis akzeptierten Werte. Gegenüber Sozialrebellen wird zur Vorsicht gemahnt, und weibliche Exzeptionali-

78 Ähnliches geschieht in der Ballade An Every-Day Hero, in: HW, 17. August 1850, S. 492-494. 
tät wird in Zeiten der aufkeimenden Frauenbewegung zwar anerkannt, gleichzeitig aber zu einem höheren moralischen Heldentum stilisiert und so in seinem Transgressivitätspotenzial eingehegt. Vorstellungen einer Polarisierung durch Helden oder der Störung der Ordnung durch widerständige Helden wird ausgewichen, was angesichts zeitgenössischer bzw. kürzlich vergangener Sozialunruhen (unter anderem Chartistenbewegung und Arbeitskonflikte in Großbritannien, Revolutionen auf dem Kontinent) auch politisch motiviert gewesen sein dürfte. Der Held als provokanter Grenzgänger und Normsprenger wird ausgeblendet und stattdessen die Aufmerksamkeit auf den Helden als vorbildlichen Normerfüller (oder sogar -übererfüller) gelenkt.

Hinter solcher Darstellung liegt eine Absicht der Egalisierung und Stabilisierung: Figuren, die viktorianische Publikumszeitschriften als heldentauglich präsentierten und propagierten, standen für hegemonial anerkannte Ideale und Werte, und sie sollten deshalb auch nicht unerreichbar über denen stehen, für die sie Helden sein sollten. Wenn sie es taten (wie etwa im Fall Wellingtons), wurde ihre Exzeptionalität so weit an das normalmenschliche Maß angeglichen, dass auch der Durchschnittsbürger in den Helden bzw. einzelnen von ihnen verkörperten Eigenschaften, Möglichkeiten der Nachahmung erkennen konnte. Eine Verehrergemeinschaft sollte das Massenpublikum der viktorianischen Zeitschriften nicht sein, wohl aber eine Gemeinschaft von Bewunderern für Helden, die die Werte ihrer Gemeinschaft nachahmenswert repräsentierten und somit für den Zusammenhalt der Gesellschaft - über alle Klassen- und Geschlechtergrenzen hinaus - in Anspruch genommen werden konnten. 